have a smattering,' he replied. 'Besides,' he added, with a twinkle, 'translating isn't just a matter of knowing the language. The original play was a tragedy - which was all right for Austria where they like tragic endings - but it would never go that way in England and America, so I turned it into a comedy!' Shaw then offered this play to the Guild.

\title{
Saint Joan in Composition
}

\author{
LADY GREGORY
}

From Lady Gregory's Journals 1916-1930, ed. Lennox Robinson (London: Putnam, 1946) pp. 211-12, 215. The following recollections are dated 19 and 23 May 1923. The composition of Saint Joan was begun on 29 April, and completed on 24 August 1923.

GBS drove me home and talked of his Joan of Arc play. He has not read Mark Twain, ${ }^{1}$ is afraid of being influenced by him. He has read a little of Anatole France ${ }^{2}$ and is reading the evidence at the trial, it was published some years ago. He does not idealise her as Mark does, and defends the Church, 'it didn't torture her'. I think there will be something good about the English soldiers. . . .

GBS just before I left read me a new scene he had written in the morning, the Relief of Orleans, in a scene between Joan and Dunois and a boy. 'The wind', long waited for, comes and is shown to the audience by the waving of the pennon. I said if I had been writing it for 'Kiltartan'3 I would have made the little boy sneeze. (And when I was going, after the play was put on, GBS said, 'You will have your sneeze.' So I did!)

\section{NOTES}

1. Mark Twain's Personal Recollections of Joan of Arc by the Sieur Louis de Conte (London: Chatto \& Windus, 1896) was presented on the title page as a translation of an original French document edited by him, in order to prevent the public from thinking it was another of his comic novels.

2. Anatole France's controversial two-volume work La Vie de Jeanne d'Arc was published in 1908.

3. 'Kiltartan' was the name used by Lady Gregory for her own style of writing in the rendering of Irish folk idiom. 